\title{
MAFLD Criteria Guide the Subtyping of Patients with Fatty Liver Disease
}

\author{
Jiaofeng Huang' \\ Weijie Ou' \\ Mingfang Wang' \\ Medha Singh ${ }^{2}$ \\ Yuxiu Liu' \\ Shiying Liu' \\ Yinlian $\mathrm{Wu}^{\prime}$ \\ Yueyong Zhu' ${ }^{1,3}$ \\ Rahul Kumar (iD) ${ }^{4, *}$ \\ Su Lin $\left(\mathbb{D}^{1}\right)^{1, *}$

\begin{abstract}
'Department of Hepatology, Hepatology Research Institute, The First Affiliated Hospital, Fujian Medical University, Fuzhou, Fujian, People's Republic of China; ${ }^{2}$ Department of General Medicine, Tan Tock Seng Hospital, Singapore; ${ }^{3}$ Fujian Key Laboratory of Precison Medicine for Cancer, The First Affiliated Hospital, Fujian Medical University, Fuzhou, Fujian, People's Republic of China; ${ }^{4}$ Department of Gastroenterology and Hepatology, DukeNUS Academic Medical Centre, Changi General Hospital, Singapore

*These authors contributed equally to this work
\end{abstract}

Correspondence: Su Lin

Department of Hepatology, Hepatology Research Institute, The First Affiliated Hospital, Fujian Medical University, No. 20, Chazhong Road, Taijiang District, Fuzhou, Fujian, 350005, People's Republic of China

Email sumer5I29@fjmu.edu.cn
This article was published in the following Dove Press journal:

Risk Management and Healthcare Policy

Background and Aims: Metabolic associated fatty liver disease (MAFLD) is diagnosed in patients with hepatic steatosis when they have the following three metabolic conditions: obesity/overweight, diabetes and metabolic dysregulation, either alone or in combination. There is no clarity whether subtypes of MAFLD diagnosed by different metabolic conditions carry different levels of risk for intra- and extra-hepatic organs. This study aims to depict the characteristics of these subtypes in a large population.

Methods: The data were retrieved from the third National Health and Nutrition Examination Surveys of the United States. The clinical and biochemical features in different MAFLD subtypes were compared. The outcome of interest was significant and advanced fibrosis.

Results: Out of 4,087 (31.24\%) participants with MAFLD, 1,165 (28.51\%) were diagnosed by single metabolic condition, $2,053(50.23 \%)$ by two conditions, and $869(21.26 \%)$ by all three metabolic conditions. With increasing numbers of metabolic conditions, participants tended to be older, were more likely to be female, and had more severe renal impairment and liver fibrosis $(P<0.05)$. MAFLD patients with a lower number of metabolic conditions were more likely to have excessive alcohol consumption. Among MAFLD with single metabolic condition, those diagnosed by diabetes alone had the highest proportion of advanced fibrosis identified by non-invasive fibrosis models $(P<0.05)$.

Conclusion: More metabolic conditions upon the diagnosis of MALFD indicate higher risk of fibrosis. Patients with MAFLD diagnosed by diabetes alone are more likely to have advanced hepatic fibrosis than those with other metabolic conditions alone. Individualized management is required for MAFLD with different subtypes.

Keywords: metabolic associated fatty liver disease, nonalcoholic fatty liver disease, metabolic syndromes, NHANES, fibrosis

\section{Introduction}

Non-alcoholic fatty liver disease (NAFLD) is one of the most common chronic liver diseases worldwide. ${ }^{1}$ It is closely associated with metabolic syndrome, insulin resistance, and obesity. ${ }^{2}$ The presence of metabolic disorders ${ }^{3,4}$ and hepatic fibrosis ${ }^{5}$ both lead to adverse outcome in patients with NAFLD.

Metabolic (dysfunction) associated fatty liver disease (MAFLD) is a novel concept proposed in 2020 aiming to replace the term NAFLD. ${ }^{6}$ Unlike NAFLD, MAFLD does not require the exclusion of other etiologies of liver disease, such as excessive alcohol consumption or viral hepatitis. ${ }^{7}$ MAFLD is diagnosed in patients when they have both hepatic steatosis and any of the following three metabolic conditions: overweight/obesity, diabetes mellitus, or evidence of metabolic dysregulation (MD) in lean individuals. ${ }^{8}$ This novel concept and criteria enable clinicians 
to identify more patients at risk of adverse outcomes in clinical practice. ${ }^{9,10}$ Since this concept was introduced recently, the utility of MAFLD in clinical practice requires further investigation. As the diagnosis of MAFLD can be achieved by fulfilling either one, two or all of the three metabolic conditions, there is no clarity whether MAFLD patients with different numbers or types of metabolic conditions have different risks of liver fibrosis. These three metabolic conditions set out for the diagnosis of MAFLD can be used to sub-classify MAFLD patients and we hypothesize that different subgroups will have various clinical characteristics and natural history. In this study, we used a survey-based dataset to subdivide groups based on whether the diagnosis of MAFLD was made by fulfilling one, two, or all three metabolic conditions and to compare the differences in clinical and biochemical characteristics among the subgroups. As the extent of hepatic fibrosis predicts mortality, ${ }^{11}$ we treated "advanced fibrosis" as the outcome measure of interest.

\section{Methods}

\section{Study Population}

The study data came from a population survey database: the third National Health and Nutrition Examination Surveys 1988-1994 (NHANES III 1988-1994). NHANES is a periodic survey conducted by the National Center for Health Statistics of the Centers for Disease Control and Prevention of the US. It is the largest survey with both biochemical and liver ultrasonography (USG) examination data thus often used for the study of fatty liver disease. ${ }^{12-16}$ The National Center for Health Statistics Research Ethics Review Board approved the NHANES study protocol and informed consent was obtained from all subjects for the survey. All the data in the NHANES database is anonymous and free to access online via https://www.cdc.gov/nchs/nhanes/about nhanes.htm This dataset has adequate clinical information allowing us to calculate the non-invasive fibrosis scores validated to be used in patients with NAFLD, ie, FIB-4 (fibrosis-4 index) or NFS (NAFLD fibrosis score).

\section{Diagnostic Criteria and Definition of Groups}

MAFLD is diagnosed based on an USG confirmed hepatic steatosis with the presence of any one of the three aforementioned metabolic conditions: diabetes mellitus, overweight/obesity, or $\mathrm{MD}^{8}$ Patients with MAFLD were further classified into three subgroups according to the presence of different numbers and types of metabolic conditions. According to MAFLD definition, MD in this study was defined as the presence of at least two of the following criteria: 1) Waist circumference $\geq 102 \mathrm{~cm}$ in men and $88 \mathrm{~cm}$ in women. 2) Pre-diabetes (glycated hemoglobin (HbAlc) of 5.7-6.4\%, or fasting plasma glucose (FPG) of 5.6-6.9 $\mathrm{mmol} / \mathrm{L}$, or 2-hour post-load glucose levels of $7.8-11.0$ $\mathrm{mmol} / \mathrm{L}$ ). 3) Blood pressure $\geq 130 / 85 \mathrm{mmHg}$ or under antihypertension therapy. 4) High-density lipoprotein cholesterol (HDL-C) $<1.0 \mathrm{mmol} / \mathrm{L}$ for males and $<1.3 \mathrm{mmol} / \mathrm{L}$ for females. 5) Triglyceride (TG) $\geq 1.70 \mathrm{mmol} / \mathrm{L}$ or specific drug treatment. 6) Homeostasis model assessment-insulin resistance (HOMA-IR) score $\geq 2.5$; and 7) Hypersensitive C-reactive protein (hs-CRP) level $>2 \mathrm{mg} / \mathrm{L}$.

NAFLD was diagnosed based on ultrasonographic evidence of fatty liver and the exclusion of any secondary causes of hepatic steatosis, such as chronic viral hepatitis or alcoholic disease (alcohol consumption $\geq 30 \mathrm{~g} /$ day for males and $20 \mathrm{~g} /$ day for females). ${ }^{17-19}$

According to the severity of liver steatosis on USG, patients were further classified as having mild, moderate, or severe liver steatosis. The grading of liver steatosis was done by using features that include liver brightness, contrast between the liver and kidney, ultrasonography appearance of the intrahepatic vessels, liver parenchyma, and diaphragm. ${ }^{20,21}$ The details of the grading can be achieved online (https://www.cdc.gov/nchs/data/nhanes/nhanes3/ Hepatic Steatosis Ultrasound Procedures Manual.pdf).

Two non-invasive models were used to assess liver fibrosis in this study, including FIB-4 and NFS. The cutoff values of FIB-4 and NFS for diagnosis of advanced fibrosis were 1.3 and -1.455 , respectively. ${ }^{22-24}$ FIB-4 and NFS were selected for the purpose of this study as these are the two validated scores for the assessment of hepatic fibrosis in patients with NAFLD. ${ }^{25}$

\section{Demographic Variables}

The following demographic variables were obtained from the original database: age, sex, and body mass index (BMI), history of hypertension and diabetes mellitus. BMI was calculated as weight (in kilograms) divided by the square of the height (in meters).

\section{Laboratory Biochemical Parameters}

The laboratory biochemical parameters retrieved from the database and studied included FPG, fasting plasma insulin, HbAlc, total cholesterol, TG, low-density lipoprotein 
cholesterol (LDL-C), HDL-C, total bilirubin, aspartate aminotransferase (AST), alanine transaminase (ALT), alkaline phosphatase (ALP), $\gamma$-glutamyl transferase (GGT), albumin, blood urea nitrogen (BUN), hs-CRP, and uric acid. All biochemical assessments were performed by standard laboratory methods. HOMA-IR was calculated as fasting insulin $(\mu \mathrm{U} / \mathrm{mL}) \times$ fasting glucose $(\mathrm{mmol} / \mathrm{L}) / 22.5$.

\section{Statistical Analysis}

The continuous variables were expressed as means \pm standard variation (SD) and the categorical variables were expressed as percentages. The Student's $t$-test (for normally distributed variables), Mann-Whitney $U$-test (for non-normally distributed variables), and Chi-squared test (for categorical variables) were used to investigate the differences between the groups. All tests were two-tailed and results with a $P$-value of less than 0.05 were considered statistically significant. All analysis was conducted using R 3.6.2 (https://www.r-project.org/).

\section{Results}

\section{Baseline Characteristics of Overall Patients}

The original NHANES III dataset included 13,857 participants with abdominal USG examination, out of which 13,083 participants had both complete relevant laboratory and USG data. After excluding 8,297 (63.42\%) participants without hepatic steatosis and 699 (5.34\%) participants without any metabolic risks, a total of 4,087 (31.24\%) participants fulfilled the criteria for MAFLD diagnosis (Figure 1: consort diagram). Among them, $2,036(49.82 \%)$ were male, and the mean age of the entire cohort was $48.39 \pm 15.2$ years and the BMI was $30.68 \pm 6.25$ $\mathrm{Kg} / \mathrm{m}^{2}$. A total of 1,171 (28.65\%) participants had diabetes and 1,463 (35.80\%) had hypertension. Amongst those diagnosed with MAFLD, 3,638 (89.01\%) participants met the previous diagnostic criteria for NAFLD and 342 $(8.37 \%)$ met that of alcoholic liver disease. Ninety $(2.20 \%)$ participants were positive for hepatitis $\mathrm{C}$ antibody and $17(0.42 \%)$ were positive for hepatitis B surface antigen; these patients would have been classified as viral hepatitis rather than NAFLD by previous NAFLD criteria. According to the severity of liver steatosis detected by USG, 1,361 (33.30\%) were graded as having mild steatosis, $1,813(44.36 \%)$ as moderate, and $913(22.34 \%)$ as severe hepatic steatosis. Of all the 4,087 participants diagnosed with MAFLD, 1,165 (28.51\%) were diagnosed by single metabolic condition, 2,053 $(50.23 \%)$ by two conditions, and $869(21.26 \%)$ by all three conditions.

\section{Comparison of Different Numbers of Metabolic Conditions}

Patients with MAFLD were divided into three groups according to the numbers of metabolic conditions (one,

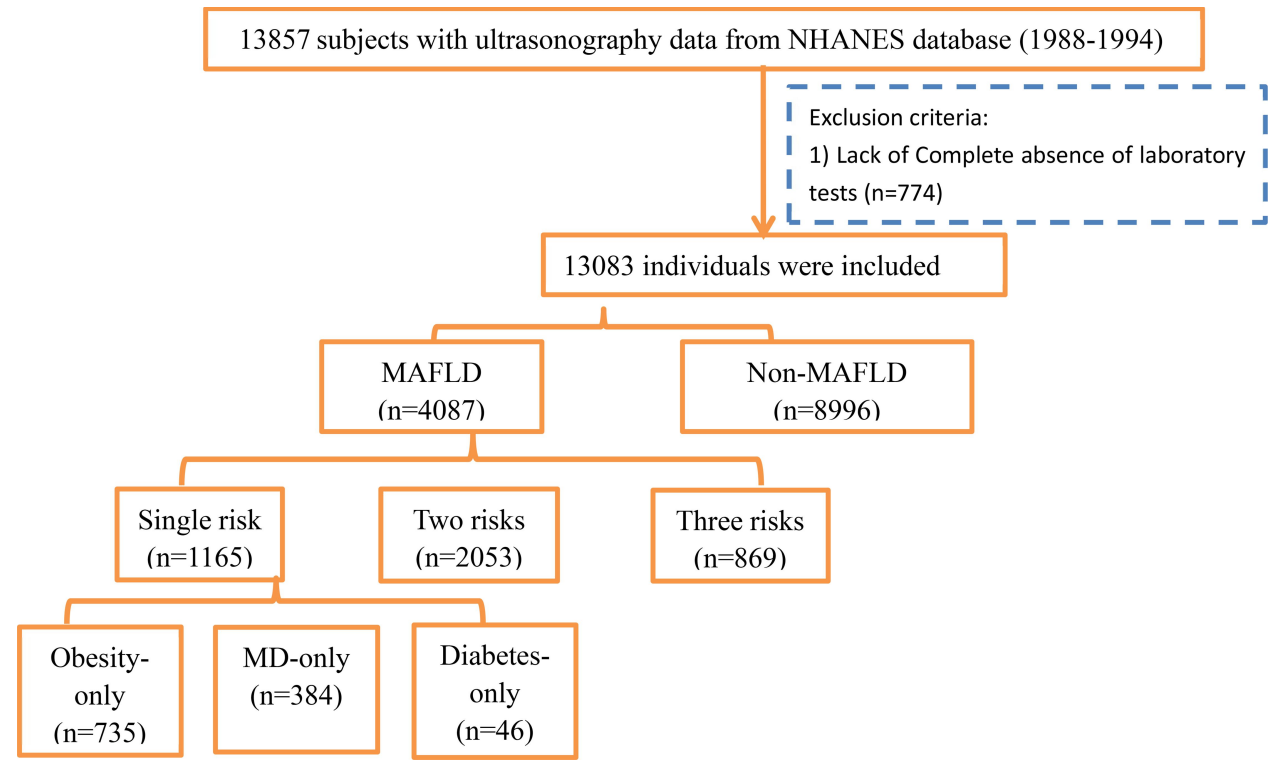

Figure I The flow chart of case selection.

Abbreviations: NHANES, National Health and Nutrition Examination Surveys; MAFLD, metabolic associated fatty liver disease; MD, metabolic dysregulation. 
two, or three) used for the diagnosis of MAFLD. The clinical parameters and the comparisons amongst the three groups are illustrated in Table 1. With the increasing number of metabolic conditions present, the participants tended to be older, more likely to be female, and had higher levels of metabolic related parameters including BMI, HOMA-IR, blood lipids, glucose levels, and hsCRP $(P<0.05)$. The serum creatinine level increased with the number of metabolic conditions while the GFR decreased with it $(P<0.05)$. Patients with less risk factors were more likely to have excessive alcohol consumption $(P<0.05)$.

Assessment of parameters of liver injury showed that the grade of hepatic steatosis, as well as GGT and ALP, were also increased with the numbers of metabolic conditions $(P<0.05)$. MAFLD with more metabolic conditions were more likely to have advanced fibrosis by assessed by NFS $(20.77 \%, 33.56 \%$, and $48.68 \%$ for 1,2 , and 3 conditions, respectively) and FIB-4 $(17.77 \%, 22.70 \%$, and $33.72 \%$, for 1,2 , and 3 conditions, respectively) (Table 1 and Figure 2A). The results of multivariate analysis showed that the number of metabolic conditions was an independent risk factor for advanced fibrosis assessed by both NFS and FIB-4 after adjusting for the severity of liver steatosis and alcohol intake in (for fibrosis assessed by NFS, OR $=1.905$, for fibrosis assessed by FIB-4, $\mathrm{OR}=1.552$, both $P<0.001$, Table 2).

\section{Characteristics of MAFLD with Single Metabolic Condition}

A total of 1,165 participants were diagnosed with MAFLD based on single metabolic condition. They were subdivided into three groups (Table 3): obese $(735,63.09 \%)$, diabetes $(384,32.96 \%)$, and MD (46, 3.95\%). Obese MAFLD was the youngest (39.6 \pm 13.69 years), and diabetic MAFLD was the oldest (52.48 \pm 14.84 years). No significant differences were found in alcohol consumption, liver enzymes (AST, GGT, and ALP) levels, grade of hepatic steatosis, and lipid levels (total cholesterol, LDLC) between these three groups. MAFLD diagnosed by obesity alone had the lowest levels of metabolic related indicators (HbA1c, FPG, TG, and HOMA-IR), while the diabetic MAFLD had the highest $(P<0.05)$. For the noninvasive liver fibrosis models, the diabetic MAFLD had highest score in FIB-4 and NFS (Figure 2B), as well as highest proportion of advanced fibrosis, while the obese MAFLD had the lowest risk of advanced fibrosis $(P<0.05)$.

\section{Discussion}

The newly proposed MAFLD criteria helps to identify more cases of fatty liver disease at risk of adverse outcomes. ${ }^{10}$ Our present study aimed to describe the clinical features of MAFLD subgroups diagnosed by different metabolic conditions. The results show that the higher the number of metabolic conditions upon the diagnosis of MAFLD, the worse the severity of hepatic steatosis and fibrosis. MAFLD with a single metabolic condition were relatively younger and had higher alcohol consumption than those with multiple conditions. MALFD diagnosed by diabetes alone had significantly severe fibrosis than MAFLD diagnosed by high BMI/obesity or MD alone. These findings are of important clinical consideration and are likely to have implications in the management of patients with MAFLD.

The new diagnostic criteria put out for MAFLD requires the presence of any of three different metabolic conditions alone or in a combination; this subsequently classifies MAFLD patients into at least three subtypes. In the current study of the NHANES III database, participants with more than one metabolic condition accounted for over $70 \%$ of all patients with MAFLD. Not surprisingly, patients with two or more metabolic conditions had a higher grade of hepatic and renal injury than those with a single one. As the presence of metabolic syndrome has already been proven by a prospective study to be related with higher mortality in NAFLD patients, ${ }^{3}$ the number of metabolic conditions upon diagnosis may help to stratify the MAFLD patients based on the future risk of adverse outcome. This sub-classification of MAFLD becomes even more important to consider as the risk of hepatic and renal impairment as well as the risk of hepatic fibrosis, which are clearly different in these sub-groups.

The results of our study showed that MAFLD patients with single metabolic conditions were significantly younger and had the lowest BMI compared to those with multiple ones. Notably, $11 \%$ of MAFLD with single metabolic condition had excessive harmful alcohol consumption, which would qualify them as alcoholic fatty liver disease based on the previous definitions. ${ }^{17}$ As alcoholrelated liver disease is one of the main causes of liver related deaths attributed to hepatocellular carcinoma and cirrhosis $^{26}$ and the mechanism of alcohol-induced liver injury is different from the NAFLD, ${ }^{27}$ sustained abstinence should be emphasized in this subgroup of patients in addition to the control of metabolic risk factors. 
Table I Comparison of the Characteristics Between MAFLD with Different Metabolic Conditions

\begin{tabular}{|c|c|c|c|c|c|c|c|c|}
\hline \multirow[t]{2}{*}{ Variables } & \multirow[t]{2}{*}{ Total } & \multirow{2}{*}{$\begin{array}{l}\text { Single } \\
\text { Condition }\end{array}$} & \multirow{2}{*}{$\begin{array}{l}\text { Two } \\
\text { Conditions }\end{array}$} & \multirow{2}{*}{$\begin{array}{l}\text { Three } \\
\text { Conditions }\end{array}$} & \multirow{2}{*}{$\begin{array}{l}\text { P Among Three } \\
\text { Groups }\end{array}$} & \multirow{2}{*}{$\begin{array}{l}P \\
\text { Single vs } \\
\text { Two }\end{array}$} & \multirow{2}{*}{$\begin{array}{l}P \\
\text { Single vs } \\
\text { Three }\end{array}$} & \multirow{2}{*}{$\begin{array}{l}P \\
\text { Two vs } \\
\text { Three }\end{array}$} \\
\hline & & & & & & & & \\
\hline $\mathrm{N}$ & 4,087 & 1,165 & 2,053 & 869 & & & & \\
\hline Age (years) & $\begin{array}{l}48.39 \\
\pm 15.20\end{array}$ & $41.70 \pm 14.99$ & $48.62 \pm 14.58$ & $56.83 \pm 12.34$ & $<0.001$ & $<0.001$ & $<0.001$ & $<0.001$ \\
\hline Male (\%) & $\begin{array}{l}2,036 \\
(49.82)\end{array}$ & $617(52.96)$ & $\begin{array}{l}1,048 \\
(51.05)\end{array}$ & $37 I(42.69)$ & $<0.001$ & 0.314 & $<0.001$ & $<0.001$ \\
\hline BMI $\left(\mathrm{Kg} / \mathrm{m}^{2}\right)$ & $\begin{array}{l}30.68 \\
\pm 6.25\end{array}$ & $27.44 \pm 5.67$ & $31.61 \pm 6.06$ & $32.82 \pm 5.78$ & $<0.001$ & $<0.001$ & $<0.001$ & $<0.001$ \\
\hline Diabetes (\%) & $\begin{array}{l}I, 171 \\
(28.65)\end{array}$ & $46(3.95)$ & $256(12.47)$ & $869(100)$ & $<0.001$ & $<0.001$ & $<0.001$ & $<0.001$ \\
\hline Hypertension (\%) & $\begin{array}{l}1,463 \\
(35.80)\end{array}$ & $170(14.59)$ & $787(38.33)$ & $506(58.23)$ & $<0.001$ & $<0.001$ & $<0.001$ & $<0.001$ \\
\hline $\begin{array}{l}\text { Hepatitis steatosis } \\
\text { (\%) }\end{array}$ & & & & & $<0.001$ & $<0.001$ & $<0.001$ & $<0.001$ \\
\hline Mild & $\begin{array}{l}1,361 \\
(33.30)\end{array}$ & $529(45.4 I)$ & $631(30.74)$ & $201(23.13)$ & & & & \\
\hline Moderate & $\begin{array}{l}1,813 \\
(44.36)\end{array}$ & $444(38.11)$ & $954(46.47)$ & $415(47.76)$ & & & & \\
\hline Severe & $\begin{array}{l}913 \\
(22.34)\end{array}$ & $192(16.48)$ & $468(22.8)$ & $253(29.11)$ & & & & \\
\hline Previous diagnosis & & & & & $<0.001$ & 0.001 & $<0.001$ & 0.083 \\
\hline NAFLD & $\begin{array}{l}3,638 \\
(89.01)\end{array}$ & 999 (85.75) & $\begin{array}{l}I, 84 I \\
(89.67)\end{array}$ & 798 (91.83) & & & & \\
\hline $\begin{array}{l}\text { Alcoholic or viral } \\
\text { hepatitis }\end{array}$ & $\begin{array}{l}449 \\
(10.99)\end{array}$ & $166(14.25)$ & $212(10.33)$ & 71 (8.17) & & & & \\
\hline Alcohol (g/Week) & $\begin{array}{l}49.14 \\
\pm \mid 26.61\end{array}$ & $\begin{array}{l}65.84 \\
\pm 150.52\end{array}$ & $\begin{array}{l}46.61 \\
\pm 120.79\end{array}$ & $32.72 \pm 99.64$ & $<0.001$ & $<0.001$ & $<0.001$ & 0.001 \\
\hline Overdrink (\%) & $\begin{array}{l}342 \\
(8.37)\end{array}$ & $121(10.39)$ & $167(8.13)$ & $54(6.21)$ & 0.003 & 0.037 & 0.001 & 0.086 \\
\hline Platelets $\left(\times 10^{9} / \mathrm{L}\right)$ & $\begin{array}{l}278.29 \\
\pm 73.05\end{array}$ & $\begin{array}{l}277.74 \\
\pm 71.42\end{array}$ & $281.31 \pm 73.9$ & $271.91 \pm 72.89$ & 0.006 & 0.181 & 0.074 & 0.002 \\
\hline BUN (mmolL) & $\begin{array}{l}5.04 \\
\pm 1.88\end{array}$ & $4.70 \pm 1.62$ & $5.06 \pm 1.74$ & $5.45 \pm 2.38$ & $<0.001$ & $<0.001$ & $<0.001$ & $<0.001$ \\
\hline Uric acid ( $\mu$ molL) & $\begin{array}{l}342.59 \\
\pm 91.68\end{array}$ & $\begin{array}{l}322.59 \\
\pm 87.22\end{array}$ & $352.9 \pm 89.62$ & $345.03 \pm 97.86$ & $<0.001$ & $<0.001$ & $<0.001$ & 0.042 \\
\hline Creatinine $(\mu \mathrm{molL})$ & $\begin{array}{l}94.7 \\
\pm 30.15\end{array}$ & $92.27 \pm 19.55$ & $95.2 \pm 28.22$ & $96.77 \pm 43.24$ & 0.002 & $<0.001$ & 0.004 & 0.324 \\
\hline GFR (mL/min) & $\begin{array}{l}77.40 \\
\pm 18.60\end{array}$ & $83.65 \pm 18.42$ & $76.35 \pm 17.35$ & $71.51 \pm 19.3$ & $<0.001$ & $<0.001$ & $<0.001$ & $<0.001$ \\
\hline
\end{tabular}


Table I (Continued).

\begin{tabular}{|c|c|c|c|c|c|c|c|c|}
\hline \multirow[t]{2}{*}{ Variables } & \multirow[t]{2}{*}{ Total } & \multirow{2}{*}{$\begin{array}{l}\text { Single } \\
\text { Condition }\end{array}$} & \multirow{2}{*}{$\begin{array}{l}\text { Two } \\
\text { Conditions }\end{array}$} & \multirow{2}{*}{$\begin{array}{l}\text { Three } \\
\text { Conditions }\end{array}$} & \multirow{2}{*}{$\begin{array}{l}\text { P Among Three } \\
\text { Groups }\end{array}$} & \multirow{2}{*}{$\begin{array}{l}P \\
\text { Single vs } \\
\text { Two }\end{array}$} & \multirow{2}{*}{$\begin{array}{l}P \\
\text { Single vs } \\
\text { Three }\end{array}$} & \multirow{2}{*}{$\begin{array}{l}P \\
\text { Two vs } \\
\text { Three }\end{array}$} \\
\hline & & & & & & & & \\
\hline TBIL ( $\mu \mathrm{molL})$ & $\begin{array}{l}10.10 \\
\pm 5.90\end{array}$ & $10.12 \pm 6.14$ & $10.07 \pm 5.92$ & $10.14 \pm 5.52$ & 0.949 & 0.827 & 0.933 & 0.758 \\
\hline ALT (U/L) & $\begin{array}{l}23.96 \\
\pm 22.22\end{array}$ & $22.55 \pm 20.32$ & $24.79 \pm 24.4$ & $23.88 \pm|8.9|$ & 0.023 & 0.005 & 0.129 & 0.280 \\
\hline AST (U/L) & $\begin{array}{l}25.35 \\
\pm 19.23\end{array}$ & $\begin{array}{l}25.29 \pm \\
19.44\end{array}$ & $25.34 \pm 19.8$ & $25.46 \pm 17.53$ & 0.981 & 0.945 & 0.840 & 0.874 \\
\hline GGT (U/L) & $\begin{array}{l}45.51 \\
\pm 68.66\end{array}$ & $41.28 \pm 173$ & $44.27 \pm 62.88$ & $53.84 \pm 76.21$ & $<0.001$ & 0.293 & $<0.001$ & 0.004 \\
\hline ALP (U/L) & $\begin{array}{l}92.42 \\
\pm 32.28\end{array}$ & $85.92 \pm 28.33$ & $92.18 \pm 31.66$ & $101.72 \pm 36.26$ & $<0.001$ & $<0.001$ & $<0.001$ & $<0.001$ \\
\hline LDH (U/L) & $\begin{array}{r}167.91 \\
\pm 39.69\end{array}$ & $\begin{array}{l}165.69 \pm \\
43.17\end{array}$ & $167.96 \pm 37.6$ & $170.75 \pm 39.5$ & 0.018 & 0.134 & 0.006 & 0.078 \\
\hline Total protein $(\mathrm{g} / \mathrm{L})$ & $\begin{array}{l}74.31 \\
\pm 4.62\end{array}$ & $74.18 \pm 4.68$ & $74.23 \pm 4.56$ & $74.69 \pm 4.65$ & 0.025 & 0.785 & 0.015 & 0.014 \\
\hline Albumin $(g / L)$ & $\begin{array}{l}41.18 \\
\pm 3.73\end{array}$ & $41.53 \pm 3.85$ & $41.26 \pm 3.66$ & $40.52 \pm 3.67$ & $<0.001$ & 0.051 & $<0.001$ & $<0.001$ \\
\hline HbAlc (\%) & $\begin{array}{l}5.91 \pm \\
1.48\end{array}$ & $5.29 \pm 0.73$ & $5.68 \pm 1.16$ & $7.30 \pm 1.95$ & $<0.001$ & $<0.001$ & $<0.001$ & $<0.001$ \\
\hline HOMA-IR score & $\begin{array}{l}3.60 \\
\pm 8.98\end{array}$ & $2.77 \pm 3.08$ & $3.9 \pm 8.41$ & $9.02 \pm 13.46$ & $<0.001$ & $<0.001$ & $<0.001$ & $<0.001$ \\
\hline FPG (mmol/L) & $\begin{array}{l}6.30 \\
\pm 2.93\end{array}$ & $5.25 \pm 1.27$ & $5.90 \pm 2.27$ & $8.68 \pm 4.3$ & $<0.001$ & $<0.001$ & $<0.001$ & $<0.001$ \\
\hline TC (mmol/L) & $\begin{array}{l}5.53 \\
\pm 1.20\end{array}$ & $5.22 \pm 1.14$ & $5.57 \pm 1.15$ & $5.82 \pm|.3|$ & $<0.001$ & $<0.001$ & $<0.001$ & $<0.001$ \\
\hline TG (mmol/L) & $\begin{array}{l}2.19 \\
\pm 1.78\end{array}$ & $1.48 \pm 1.01$ & $2.29 \pm 1.56$ & $2.94 \pm 2.56$ & $<0.001$ & $<0.001$ & $<0.001$ & $<0.001$ \\
\hline LDL-C (mmol/L) & $\begin{array}{l}3.38 \\
\pm 1.00\end{array}$ & $3.19 \pm 0.98$ & $3.47 \pm 1.00$ & $3.45 \pm 0.98$ & $<0.001$ & $<0.001$ & $<0.001$ & 0.739 \\
\hline $\mathrm{Hs}-\mathrm{CRP}(\mathrm{mg} / \mathrm{L})$ & $\begin{array}{l}5.55 \\
\pm 8.16\end{array}$ & $4.12 \pm 5.80$ & $5.48 \pm 8.02$ & $7.66 \pm 10.43$ & $<0.001$ & $<0.001$ & $<0.001$ & $<0.001$ \\
\hline HDL-C (mmol/L) & $\begin{array}{l}1.19 \\
\pm 0.37\end{array}$ & $1.32 \pm 0.40$ & $1.15 \pm 0.34$ & $1.10 \pm 0.33$ & $<0.001$ & $<0.001$ & $<0.001$ & $<0.001$ \\
\hline NFS score & $\begin{array}{l}-2.05 \\
\pm|.5|\end{array}$ & $-2.53 \pm 1.44$ & $-2.04 \pm 1.50$ & $-1.45 \pm 1.39$ & $<0.001$ & $<0.001$ & $<0.001$ & $<0.001$ \\
\hline $\begin{array}{l}\text { NFS score >-I.455, } \\
\text { n (\%) }\end{array}$ & $\begin{array}{l}1,354 \\
(33.13)\end{array}$ & $242(20.77)$ & 689 (33.56) & $423(48.68)$ & $<0.001$ & $<0.001$ & $<0.001$ & $<0.001$ \\
\hline
\end{tabular}

(Continued) 
Table I (Continued).

\begin{tabular}{|c|c|c|c|c|c|c|c|c|}
\hline \multirow[t]{2}{*}{ Variables } & \multirow[t]{2}{*}{ Total } & \multirow{2}{*}{$\begin{array}{l}\text { Single } \\
\text { Condition }\end{array}$} & \multirow{2}{*}{$\begin{array}{l}\text { Two } \\
\text { Conditions }\end{array}$} & \multirow{2}{*}{$\begin{array}{l}\text { Three } \\
\text { Conditions }\end{array}$} & \multirow{2}{*}{$\begin{array}{l}\text { P Among Three } \\
\text { Groups }\end{array}$} & $P$ & $P$ & $P$ \\
\hline & & & & & & $\begin{array}{l}\text { Single vs } \\
\text { Two }\end{array}$ & $\begin{array}{l}\text { Single vs } \\
\text { Three }\end{array}$ & $\begin{array}{l}\text { Two vs } \\
\text { Three }\end{array}$ \\
\hline FIB-4 score & $\begin{array}{l}1.06 \\
\pm 1.35\end{array}$ & $0.94 \pm 0.90$ & $1.03 \pm 0.79$ & $1.30 \pm 2.43$ & $<0.001$ & 0.006 & $<0.001$ & $<0.001$ \\
\hline $\begin{array}{l}\text { FIB-4 score >I.3, } \\
n(\%)\end{array}$ & $\begin{array}{l}966 \\
(23.64)\end{array}$ & 207 (I7.77) & $466(22.70)$ & $293(33.72)$ & $<0.001$ & $<0.001$ & $<0.001$ & $<0.001$ \\
\hline
\end{tabular}

Abbreviations: NHANES, National Health and Nutrition Examination Surveys; MAFLD, metabolic associated fatty liver disease; NAFLD, nonalcoholic fatty liver disease; MD, metabolic dysregulation; BMI, body mass index; ALT, alanine aminotransferase; AST, aspartate aminotransferase; GGT, $\gamma$-glutamyl transpeptidase; ALP, alkaline phosphatase; LDH, lactate dehydrogenase; TG, triglyceride; TC, total cholesterol; HDL-C, high-density lipoprotein cholesterol; LDL-C, low-density lipoprotein cholesterol; HOMA-IR score, homeostasis model assessment-insulin resistance; HbAlc, glycated hemoglobin; FPG, fasting plasma glucose; BUN, blood urea nitrogen; Hs-CRP, highsensitivity serum C-reactive protein; FIB-4, fibrosis-4 index; NFS, NAFLD fibrosis score.

Another important finding of our study pertains to the characterization of patients diagnosed with MAFLD by fulfilling only one criterion out of the three proposed

\section{A}

Single condition $\square$ Two conditions $\square$ Three conditions

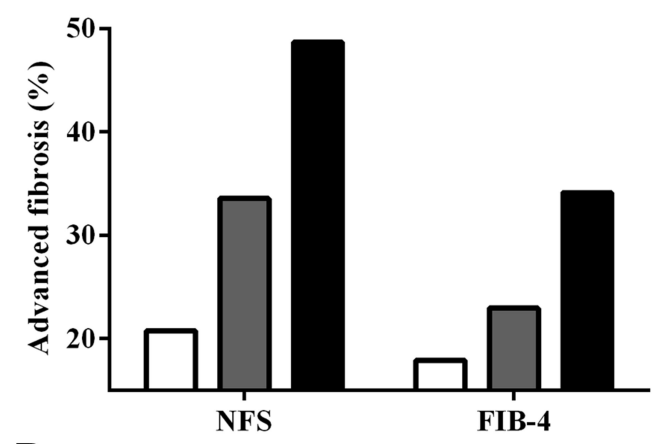

B
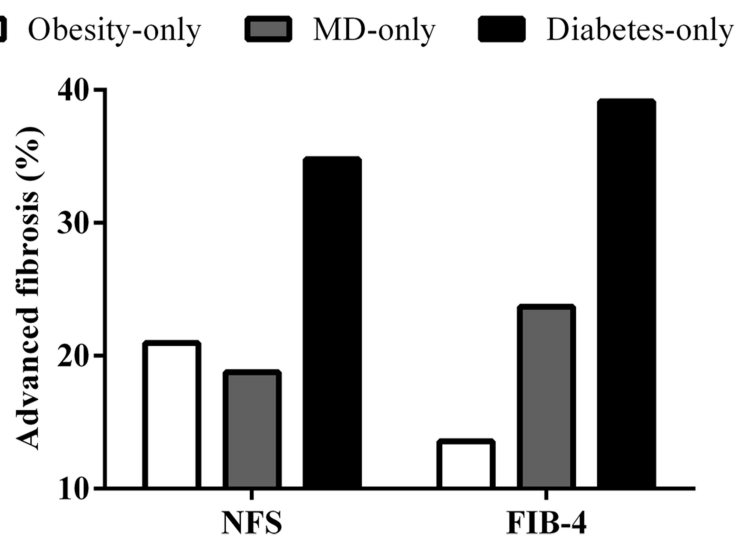

Figure 2 The proportion of advanced liver fibrosis assessed in different noninvasive fibrosis models. (A) The advanced liver fibrosis increased with the number of metabolic conditions. (B) The advanced liver fibrosis is more common in the diabetes-only groups.

Abbreviations: MD, metabolic dysregulation; FIB-4, fibrosis-4 index; NFS, NAFLD fibrosis score. metabolic conditions. In general, no difference in the $\mathrm{TC}$, LDL-C levels, as well as the severity of hepatic steatosis and liver enzymes was observed amongst the three groups, which may indicate that these three metabolic conditions are equally important for the diagnosis of MAFLD. It is important to note that MAFLD diagnosed based on diabetes alone showed slightly different characteristics from the other two groups: these patients were older and exhibited a higher grade of hepatic fibrosis than the rest, which is in line with previous reports that diabetes was associated with liver fibrosis and prognosis of NAFLD. ${ }^{28-30}$ The severe fibrosis in MAFLD with diabetes alone might result

Table 2 Multivariate Analysis for Advanced Fibrosis in MAFLD Population

\begin{tabular}{|l|l|l|l|l|}
\hline $\begin{array}{l}\text { Noninvasive } \\
\text { Models }\end{array}$ & Variables & OR & $95 \%$ CI & $\boldsymbol{P}$ \\
\hline NFS & $\begin{array}{l}\text { Metabolic } \\
\text { conditions } \\
\text { Severity of } \\
\text { hepatitis } \\
\text { steatosis } \\
\text { Excessive } \\
\text { alcohol intake }\end{array}$ & 1.905 & $1.726-2.102$ & $<0.001$ \\
\hline FIB-4 & $\begin{array}{l}\text { Metabolic } \\
\text { conditions } \\
\text { Severity of } \\
\text { hepatitis } \\
\text { steatosis } \\
\text { Excessive } \\
\text { alcohol intake }\end{array}$ & 1.784 & $0.608-1.0111$ & 0.060 \\
\hline
\end{tabular}

Note: Excessive alcohol intake, an alcohol consumption $\geq 30 \mathrm{~g} /$ day for males and 20 g/day for females.

Abbreviations: FIB-4, fibrosis-4 index; NFS, NAFLD fibrosis score. 
Table 3 Comparison of the Characteristics Between Different Subtypes with Single Risk

\begin{tabular}{|c|c|c|c|c|c|c|c|}
\hline \multirow[t]{2}{*}{ Variables } & \multirow{2}{*}{$\begin{array}{l}\text { Obesity- } \\
\text { Only }\end{array}$} & \multirow{2}{*}{$\begin{array}{l}\text { MD- } \\
\text { Only }\end{array}$} & \multirow{2}{*}{$\begin{array}{l}\text { Diabetes- } \\
\text { Only }\end{array}$} & \multirow{2}{*}{$\begin{array}{l}\text { P Among Three } \\
\text { Groups }\end{array}$} & \multirow{2}{*}{$\begin{array}{l}P \\
\begin{array}{l}\text { Obesity vs } \\
\text { MD }\end{array}\end{array}$} & \multirow{2}{*}{$\begin{array}{l}P \\
\begin{array}{l}\text { Obesity vs } \\
\text { Diabetes }\end{array}\end{array}$} & \multirow{2}{*}{$\begin{array}{l}P \\
\begin{array}{l}\text { Diabetes vs } \\
\text { MD }\end{array}\end{array}$} \\
\hline & & & & & & & \\
\hline $\mathrm{N}$ & 735 & 384 & 46 & & & & \\
\hline Age (years) & $39.6 \pm 13.69$ & $\begin{array}{l}44.42 \\
\pm 16.37\end{array}$ & $52.48 \pm 14.84$ & $<0.001$ & $<0.001$ & $<0.001$ & 0.001 \\
\hline Male (\%) & $394(53.61)$ & $192(50)$ & 31 (67.39) & 0.070 & 0.279 & 0.095 & 0.038 \\
\hline BMI $\left(\mathrm{Kg} / \mathrm{m}^{2}\right)$ & $30.46 \pm 4.86$ & $\begin{array}{l}22.27 \\
\pm 2.07\end{array}$ & $22.07 \pm 2.26$ & $<0.001$ & $<0.001$ & $<0.001$ & 0.567 \\
\hline Diabetes (\%) & $0(0)$ & $0(0)$ & $46(100)$ & $<0.001$ & 1.000 & $<0.001$ & $<0.001$ \\
\hline Hypertension (\%) & $61(8.30)$ & $\begin{array}{l}104 \\
(27.08)\end{array}$ & $5(10.87)$ & $<0.001$ & $<0.001$ & 0.580 & 0.027 \\
\hline Hepatic steatosis (\%) & & & & 0.151 & 0.174 & 0.278 & 0.113 \\
\hline Mild & $321(43.67)$ & $\begin{array}{l}190 \\
(49.48)\end{array}$ & $18(39.13)$ & & & & \\
\hline Moderate & $290(39.46)$ & $\begin{array}{l}138 \\
(35.94)\end{array}$ & $16(34.78)$ & & & & \\
\hline Severe & $124(16.87)$ & $56(14.58)$ & $12(26.09)$ & & & & \\
\hline Previous diagnosis & & & & 0.014 & 0.006 & 0.965 & 0.282 \\
\hline NAFLD & $645(87.76)$ & $\begin{array}{l}313 \\
(81.51)\end{array}$ & $41(89.13)$ & & & & \\
\hline $\begin{array}{l}\text { Alcoholic or viral } \\
\text { hepatitis }\end{array}$ & $90(12.24)$ & 71 (18.49) & $5(10.87)$ & & & & \\
\hline Alcohol (g/Week) & $\begin{array}{l}62.39 \\
\pm|3| .15\end{array}$ & $\begin{array}{l}69.81 \\
\pm 171.3\end{array}$ & $\begin{array}{l}87.73 \\
\pm 234.38\end{array}$ & 0.444 & 0.458 & $0.47 \mid$ & 0.617 \\
\hline Overdrink (\%) & $70(9.52)$ & $46(11.98)$ & $5(10.87)$ & 0.425 & 0.240 & 0.795 & 1.000 \\
\hline Platelets $\left(\times 10^{9} / \mathrm{L}\right)$ & $\begin{array}{l}279.26 \\
\pm 68.91\end{array}$ & $\begin{array}{l}277.65 \\
\pm 73.20\end{array}$ & $\begin{array}{l}254.36 \\
\pm 90.91\end{array}$ & 0.072 & 0.723 & 0.074 & 0.100 \\
\hline BUN (mmol/L) & $4.68 \pm 1.52$ & $4.69 \pm 1.7 \mid$ & $5.2 \pm 2.34$ & 0.106 & 0.942 & 0.143 & 0.156 \\
\hline Uric acid $(\mu \mathrm{mol} / \mathrm{L})$ & $\begin{array}{l}331.04 \\
\pm 83.83\end{array}$ & $\begin{array}{l}309.16 \\
\pm 92.69\end{array}$ & $\begin{array}{l}299.72 \\
\pm 76.22\end{array}$ & $<0.001$ & $<0.001$ & 0.01 & 0.442 \\
\hline Creatinine $(\mu \mathrm{mol} / \mathrm{L})$ & $\begin{array}{l}92.11 \\
\pm 17.01\end{array}$ & $\begin{array}{l}91.74 \\
\pm 19.62\end{array}$ & $99.17 \pm 42.81$ & 0.048 & 0.751 & 0.272 & 0.251 \\
\hline GFR (mL/min) & $\begin{array}{l}84.82 \\
\pm 17.82\end{array}$ & $\begin{array}{l}81.82 \\
\pm 18.92\end{array}$ & $80.22 \pm 22.07$ & 0.015 & 0.010 & 0.172 & 0.639 \\
\hline TBIL $(\mu \mathrm{mol} / \mathrm{L})$ & $10.17 \pm 5.76$ & $\begin{array}{l}10.03 \\
\pm 6.97\end{array}$ & $9.89 \pm 4.23$ & 0.905 & 0.734 & 0.667 & $0.84 I$ \\
\hline ALT (U/L) & $\begin{array}{l}24.08 \\
\pm 20.85\end{array}$ & $\begin{array}{l}19.68 \\
\pm 18.91\end{array}$ & $22.07 \pm 20.98$ & 0.003 & $<0.001$ & 0.530 & 0.466 \\
\hline
\end{tabular}

(Continued) 
Table 3 (Continued).

\begin{tabular}{|c|c|c|c|c|c|c|c|}
\hline \multirow[t]{2}{*}{ Variables } & \multirow{2}{*}{$\begin{array}{l}\text { Obesity- } \\
\text { Only }\end{array}$} & \multirow{2}{*}{$\begin{array}{l}\text { MD- } \\
\text { Only }\end{array}$} & \multirow{2}{*}{$\begin{array}{l}\text { Diabetes- } \\
\text { Only }\end{array}$} & \multirow{2}{*}{$\begin{array}{l}\text { P Among Three } \\
\text { Groups }\end{array}$} & \multirow{2}{*}{$\begin{array}{l}P \\
\begin{array}{l}\text { Obesity vs } \\
\text { MD }\end{array}\end{array}$} & \multirow{2}{*}{$\begin{array}{l}P \\
\text { Obesity vs } \\
\text { Diabetes }\end{array}$} & \multirow{2}{*}{$\begin{array}{l}P \\
\begin{array}{l}\text { Diabetes vs } \\
\text { MD }\end{array}\end{array}$} \\
\hline & & & & & & & \\
\hline AST (U/L) & $\begin{array}{l}25.57 \\
\pm 21.54\end{array}$ & $\begin{array}{l}24.48 \\
\pm 14.10\end{array}$ & $27.65 \pm 22.5 I$ & 0.475 & 0.311 & 0.544 & 0.355 \\
\hline GGT (U/L) & $\begin{array}{l}38.19 \\
\pm 63.53\end{array}$ & $\begin{array}{l}45.08 \\
\pm 82.72\end{array}$ & $58.36 \pm 90.64$ & 0.138 & 0.205 & 0.197 & 0.406 \\
\hline ALP (U/L) & $\begin{array}{l}85.30 \\
\pm 25.43\end{array}$ & $\begin{array}{l}86.27 \\
\pm 32.45\end{array}$ & $92.98 \pm 34.50$ & 0.195 & 0.611 & 0.144 & 0.215 \\
\hline LDH (U/L) & $\begin{array}{l}168.99 \\
\pm 47.07\end{array}$ & $\begin{array}{l}159.14 \\
\pm 34.27\end{array}$ & $\begin{array}{l}167.78 \\
\pm 39.07\end{array}$ & 0.001 & $<0.001$ & 0.842 & 0.157 \\
\hline Total protein $(\mathrm{g} / \mathrm{L})$ & $73.98 \pm 4.48$ & $74.5 \pm 4.79$ & $74.7 \pm 6.50$ & 0.164 & 0.082 & 0.468 & 0.842 \\
\hline Albumin $(g / L)$ & $41.47 \pm 3.87$ & $\begin{array}{l}41.73 \\
\pm 3.73\end{array}$ & $40.78 \pm 4.47$ & 0.235 & 0.287 & 0.311 & 0.175 \\
\hline HbAlc (\%) & $5.20 \pm 0.43$ & $\begin{array}{l}5.27 \pm \\
0.51\end{array}$ & $6.96 \pm 2.37$ & $<0.001$ & 0.024 & $<0.001$ & $<0.001$ \\
\hline HOMA-IR score & $2.83 \pm 2.4 \mathrm{I}$ & $2.25 \pm 1.64$ & $6.20 \pm 10.82$ & $<0.001$ & $<0.001$ & $<0.001$ & $<0.001$ \\
\hline FPG (mmol/L) & $5.09 \pm 0.42$ & $5.2 \pm 0.56$ & $8.34 \pm 5.17$ & $<0.001$ & $<0.001$ & $<0.001$ & $<0.001$ \\
\hline $\mathrm{TC}(\mathrm{mmol} / \mathrm{L})$ & $5.2 \pm 1.04$ & $5.24 \pm 1.30$ & $5.39 \pm 1.15$ & 0.492 & 0.581 & 0.278 & 0.419 \\
\hline TG (mmol/L) & $1.33 \pm 0.79$ & $1.74 \pm 1.29$ & $1.49 \pm 1.00$ & $<0.001$ & $<0.001$ & 0.304 & 0.124 \\
\hline LDL-C (mmol/L) & $3.22 \pm 0.93$ & $3.14 \pm 1.08$ & $3.08 \pm 0.86$ & 0.615 & 0.391 & 0.594 & 0.829 \\
\hline $\mathrm{Hs}-\mathrm{CRP}(\mathrm{mg} / \mathrm{L})$ & $3.79 \pm 3.23$ & $4.81 \pm 8.97$ & $3.69 \pm 3.19$ & 0.017 & 0.031 & 0.839 & 0.089 \\
\hline HDL-C (mmol/L) & $1.34 \pm 0.33$ & $1.27 \pm 0.49$ & $1.52 \pm 0.57$ & $<0.001$ & 0.023 & 0.041 & 0.008 \\
\hline NFS score & $-2.44 \pm 1.36$ & $\begin{array}{l}-2.74 \\
\pm 1.52\end{array}$ & $-2.22 \pm 1.66$ & 0.001 & $<0.001$ & 0.376 & 0.047 \\
\hline $\begin{array}{l}\text { NFS score }>-1.455 \text {, } \\
\text { n (\%) }\end{array}$ & I54 (20.95) & $72(18.75)$ & $16(34.78)$ & 0.040 & 0.428 & 0.043 & 0.019 \\
\hline FIB4 score & $0.86 \pm 0.96$ & $1.02 \pm 0.64$ & $1.52 \pm 1.33$ & $<0.001$ & $<0.001$ & 0.002 & 0.015 \\
\hline FIB-4 score >I.3, n (\%) & 99 (13.47) & $90(23.44)$ & $18(39.13)$ & $<0.001$ & $<0.001$ & $<0.001$ & 0.036 \\
\hline
\end{tabular}

Abbreviations: MD, metabolic dysregulation; MAFLD, metabolic associated fatty liver disease; BMI, body mass index; NAFLD, non-alcoholic fatty liver disease; ALD, alcoholic liver disease; BUN, blood urea nitrogen; GFR, glomerular filtration rate; TBIL, total bilirubin; ALT, alanine aminotransferase; AST, aspartate aminotransferase; GGT, $\gamma$-glutamyl transpeptidase; ALP, alkaline phosphatase; LDH, lactate dehydrogenase; HbAlc, glycated hemoglobin; HOMA-IR score, homeostasis model assessment-insulin resistance; FPG, fasting plasma glucose; TC, total cholesterol; TG, triglyceride; LDL-C, low-density lipoprotein cholesterol; HDL-C, high-density lipoprotein cholesterol; HsCRP, high-sensitivity serum C-reactive protein; NFS, NAFLD fibrosis score; FIB-4, fibrosis-4 index.

from the older age of this group because hepatic fibrosis is a chronic process closely related to advancing age. On the other hand, diabetes and hepatic steatosis share several molecular biological mechanisms, the most important of which is insulin resistance. ${ }^{31}$ Insulin resistance develops long before diabetes. Thus, for a patient with liver fibrosis and diabetes, the impact of insulin resistance on the liver may have been longer than expected, which could explain the reason why the presence of diabetes might accelerate the progression of liver fibrosis. ${ }^{32}$

The strength of this study is that, to our knowledge, this is the first attempt to characterize different subtypes of 
MAFLD patients in a large population. Our data shows that subtyping MAFLD is essential as different subtypes exhibit different clinical and biochemical characteristics. This research data from a large survey-based database makes the results even more convincing. Our study, however, should be interpreted in light of some limitations. The first of which is regarding the diagnosis of hepatic steatosis, as the original study was a population-based survey, the gold-standard of hepatic steatosis, liver biopsy, was not performed in every participant. Although a limitation from an academic point of view, the USG based diagnosis of liver steatosis is as close as possible to clinical practice where histopathology is neither recommended nor feasible for the diagnosis of hepatic steatosis. $^{33}$ Second, this study uses a western dataset, whether the subtypes of MAFLD described by us will be applicable in an eastern population remains unknown. Third, with the newly christened term MAFLD, current or past/treated viral hepatitis and its interaction with metabolic dysfunctions may present as an additional level of complexity in sub-categorizing patients with MAFLD. Last, the participants are relatively "healthy" people and liver cirrhosis is rare in this population. Thus, it is not possible to validate the conclusions of our study in cirrhosis based on the current database.

In conclusion, the more the metabolic condition upon the diagnosis of MAFLD, the more severe the hepatic and the renal injury are. Patients with MAFLD diagnosed by a single metabolic condition are more likely to have excessive alcohol consumption. Patients with MAFLD diagnosed by diabetes alone tend to have a higher risk of advanced hepatic fibrosis than those with other single metabolic conditions alone. Individualized management is required for MAFLD with different metabolic risks.

\section{Abbreviations}

NHANES, National Health and Nutrition Examination Surveys; MAFLD, metabolic associated fatty liver disease; NAFLD, nonalcoholic fatty liver disease; MD, metabolic dysregulation; USG, ultrasonography; BMI, body mass index; ALT, alanine aminotransferase; AST, aspartate aminotransferase; GGT, $\gamma$-glutamyl transpeptidase; ALP, alkaline phosphatase; LDH, lactate dehydrogenase; TG, triglyceride; HDL-C, high-density lipoprotein cholesterol; LDL-C, low-density lipoprotein cholesterol; HOMA-IR score, homeostasis model assessment-insulin resistance; HbAlc, glycated hemoglobin; FPG, fasting plasma glucose; BUN, blood urea nitrogen; Hs-
CRP, high-sensitivity serum C-reactive protein; FIB-4, fibrosis-4 index; NFS, NAFLD fibrosis score.

\section{Author Contributions}

All authors made a significant contribution to the work reported, whether that is in the conception, study design, execution, acquisition of data, analysis and interpretation, or in all these areas; took part in drafting, revising, or critically reviewing the article; gave final approval of the version to be published; have agreed on the journal to which the article has been submitted; and agree to be accountable for all aspects of the work. Both Rahul Kumar and $\mathrm{Su}$ Lin contributed equally and are joint senior authors.

\section{Funding}

This research is supported by Chinese National 13th FiveYear Plan's Science and Technology Projects (2017ZX10202201), Qingzhong Medical Science Research Fund (B17344) and Startup Fund for Scientific Research, Fujian Medical University (2018QH1047).

\section{Disclosure}

The authors declare that they have no conflicts of interest in this work.

\section{References}

1. Younossi ZM, Koenig AB, Abdelatif D, et al. Global epidemiology of nonalcoholic fatty liver disease-Meta-analytic assessment of prevalence, incidence, and outcomes. Hepatology. 2016;64:73-84. doi: $10.1002 /$ hep. 28431

2. Dietrich P, Hellerbrand C. Non-alcoholic fatty liver disease, obesity and the metabolic syndrome. Best Pract Res Clin Gastroenterol. 2014;28:637-653. doi:10.1016/j.bpg.2014.07.008

3. Golabi P, Otgonsuren M, de Avila L, et al. Components of metabolic syndrome increase the risk of mortality in nonalcoholic fatty liver disease (NAFLD). Medicine. 2018;97:e214. doi:10.1097/ MD.0000000000010214

4. Huang J, Jing M, Wang C, et al. The impact of hepatitis B virus infection status on the prevalence of nonalcoholic fatty liver disease: a population-based study. $J$ Med Virol. 2020;92:1191-1197. doi:10.1002/jmv. 25621

5. Dulai PS, Singh S, Patel J, et al. Increased risk of mortality by fibrosis stage in nonalcoholic fatty liver disease: systematic review and meta-analysis. Hepatology. 2017;65:1557-1565. doi:10.1002/ hep. 29085

6. Eslam M, Sanyal AJ, George J. MAFLD: a consensus-driven proposed nomenclature for metabolic associated fatty liver disease. Gastroenterology. 2020;158:1999-2014.e1991. doi:10.1053/j. gastro.2019.11.312

7. Eslam M, Sarin SK, Wong VW, et al. The Asian Pacific Association for the Study of the Liver clinical practice guidelines for the diagnosis and management of metabolic associated fatty liver disease. Hepatol Int. 2020. 
8. Eslam M, Newsome P, Sarin S, et al. A new definition for metabolic dysfunction-associated fatty liver disease: an international expert consensus statement. J Hepatol. 2020;73:202-209. doi:10.1016/j. jhep.2020.03.039

9. Yamamura S, Eslam M, Kawaguchi T, et al. MAFLD identifies patients with significant hepatic fibrosis better than NAFLD. Liver Int. 2020;40(12):3018-3030. doi:10.1111/liv.14675

10. Lin S, Huang J, Wang M, et al. Comparison of MAFLD and NAFLD diagnostic criteria in real world. Liver Int. 2020;40:2082-2089. doi:10.1111/liv. 14548

11. Sung K, Johnston M, Lee M, et al. Non-invasive liver fibrosis scores are strongly associated with liver cancer mortality in general population without liver disease. Liver Int. 2020;40:1303-1315. doi:10.1111/liv.14416

12. Huang J, Zhang H, Liu S, et al. Is Toxoplasma gondii infection correlated with nonalcoholic fatty liver disease? A population-based study. BMC Infect Dis. 2018;18:629. doi:10.1186/s12879-018-3547-1

13. Liu Y, Wan B, Lin S. Letter: significant burden of nonalcoholic fatty liver disease with advanced fibrosis in the USA: a cross-sectional analysis of 2011-2014 National Health and Nutrition Examination Survey. Aliment Pharmacol Ther. 2018;48:584-585. doi:10.1111/ apt. 14850

14. Sirota JC, McFann K, Targher G, et al. Association between nonalcoholic liver disease and chronic kidney disease: an ultrasound analysis from NHANES 1988-1994. Am J Nephrol. 2012;36:466-471. doi:10.1159/000343885

15. Liu S, Liu Y, Wan B, et al. Association between vitamin D status and non-alcoholic fatty liver disease: a population-based study. J Nutr Sci Vitaminol (Tokyo). 2019;65:303-308. doi:10.3177/jnsv.65.303

16. Zhang M, Lin S, Wang MF, et al. Association between NAFLD and risk of prevalent chronic kidney disease: why there is a difference between east and west? BMC Gastroenterol. 2020;20:139. doi:10.1186/s12876-020-01278-z

17. European Association for the Study of the Liver. EASL Clinical Practice Guidelines: management of alcohol-related liver disease. J Hepatol. 2018;69:154-181. doi:10.1016/j.jhep.2018.03.018

18. Ratziu V, Bellentani S, Cortez-Pinto H, et al. A position statement on NAFLD/NASH based on the EASL 2009 special conference. J Hepatol. 2010;53:372-384. doi:10.1016/j.jhep.2010.04.008

19. EASL-EASD-EASO Clinical Practice Guidelines for the management of non-alcoholic fatty liver disease. $J$ Hepatol. 2016;64:1388-1402. doi:10.1016/j.jhep.2015.11.004

20. Kim SH, Lee JM, Kim JH, et al. Appropriateness of a donor liver with respect to macrosteatosis: application of artificial neural networks to US images-initial experience. Radiology. 2005;234:793-803. doi:10.1148/radiol.2343040142

Risk Management and Healthcare Policy

\section{Publish your work in this journal}

Risk Management and Healthcare Policy is an international, peerreviewed, open access journal focusing on all aspects of public health, policy, and preventative measures to promote good health and improve morbidity and mortality in the population. The journal welcomes submitted papers covering original research, basic science, clinical \& epidemiological studies, reviews and evaluations,
21. Hernaez R, Lazo M, Bonekamp S, et al. Diagnostic accuracy and reliability of ultrasonography for the detection of fatty liver: a meta-analysis. Hepatology. 2011;54:1082-1090. doi:10.1002/ hep. 24452

22. Angulo P, Hui JM, Marchesini G, et al. The NAFLD fibrosis score: a noninvasive system that identifies liver fibrosis in patients with NAFLD. Hepatology. 2007;45:846-854. doi:10.1002/hep.21496

23. Sterling RK, Lissen E, Clumeck N, et al. Development of a simple noninvasive index to predict significant fibrosis in patients with HIV/ HCV coinfection. Hepatology. 2006;43:1317-1325. doi:10.1002/ hep. 21178

24. Sun W, Cui H, Li N, et al. Comparison of FIB-4 index, NAFLD fibrosis score and BARD score for prediction of advanced fibrosis in adult patients with non-alcoholic fatty liver disease: a meta-analysis study. Hepatol Res. 2016;46:862-870. doi:10.1111/hepr.12647

25. Anstee QM, Lawitz EJ, Alkhouri N, et al. Noninvasive tests accurately identify advanced fibrosis due to NASH: baseline data from the STELLAR trials. Hepatology. 2019;70:1521-1530. doi:10.1002/ hep. 30842

26. Paik JM, Golabi P, Biswas R, et al. Nonalcoholic fatty liver disease and alcoholic liver disease are major drivers of liver mortality in the United States. Hepatol Commun. 2020;4:890-903. doi:10.1002/ hep4.1510

27. Lackner C, Tiniakos D. Fibrosis and alcohol-related liver disease. J Hepatol. 2019;70:294-304. doi:10.1016/j.jhep.2018.12.003

28. Arya S, Haria JM, Mishra A. To study the occurrence of non-alcoholic fatty liver disease (NAFLD) in type -II diabetes mellitus. J Assoc Physicians India. 2020;68:51.

29. Wang N, Wang Y, Zhang W, et al. C-peptide is associated with NAFLD inflammatory and fibrotic progression in type 2 diabetes. Diabetes Metab Res Rev. 2020;36:e3210. doi:10.1002/dmrr.3210

30. Younossi ZM, Golabi P, de Avila L, et al. The global epidemiology of NAFLD and NASH in patients with type 2 diabetes: a systematic review and meta-analysis. J Hepatol. 2019;71:793-801. doi:10.1016/ j.jhep.2019.06.021

31. Tilg H, Moschen AR, Roden M. NAFLD and diabetes mellitus. Nat Rev Gastroenterol Hepatol. 2017;14:32-42. doi:10.1038/ nrgastro.2016.147

32. Li X, Jiao Y, Xing Y, et al. Diabetes mellitus and risk of hepatic fibrosis/cirrhosis. Biomed Res Int. 2019;2019:5308308.

33. Castera L, Friedrich-Rust M, Loomba R. Noninvasive assessment of liver disease in patients with nonalcoholic fatty liver disease. Gastroenterology. 2019;156:1264-1281.e1264. doi:10.1053/j. gastro.2018.12.036 guidelines, expert opinion and commentary, case reports and extended reports. The manuscript management system is completely online and includes a very quick and fair peer-review system, which is all easy to use. Visit http://www.dovepress.com/testimonials.php to read real quotes from published authors. 